\title{
Manusmrti 7.114
}

\section{沼田一郎}

はじめに

dharma 文献史の上で Manusmrti は一つのエポックである. dharmasūtra の延長線 上にありながら, 内容・形式の両面で格段の違いがある ${ }^{1}$. しかし Yājñavalkyasmrti のような緊密な構成を持ってはいないように思われる. 従って, その成立について は章単位あるいは扱うトピックごとに分けて考える必要があると言える.

dharma-, śrauta-grhya-sūtra や MBh などの他文献との影響関係や類似句の比定と いう点では Bühler ${ }^{2)}$ や, G. Jhāによる詳細な研究 ${ }^{3)}$ が既にあるが, 本稿では注釈の 記述を手がかりとして Manuの本文テキストについて検討してみたい.

現存する Manu の註釈の中でしばしば出版され,また翻訳の際の底本とされるの は Kullūka の Manvarthamuktāvalīである.これより古い Medhātithi の Manubhāṣya は Jhā が出版・翻訳したもの ${ }^{4)}$ が標準であるが, 必ずしも良好な読みを提示しない.

J. D. M. Derrett は現存最古の註釈 Bhāruci の Manuśāstravivaraṇa を出版・翻訳し ${ }^{5)}$, またそれに先立って特に第 7 章における Medh との関係を論じた ${ }^{6}$. それによると， 両者の一致する箇所では多くの場合 Kautịlya の Arthaśāstra との一致が見られる.D. Schlingloff は Derrett 以前に Medh と Kaut との関係を指摘し, Kaut $\rightarrow$ Bhār $\rightarrow$ Medh と いう直接の影響関係を否定した ${ }^{7)}$ が, Derrett は第 7 章以外の全ての章 ${ }^{8)}$ で Bhār と Medh の間に明らかな引用関係があることを証明した ${ }^{9}$.

このように, 特に第 7 章については注釈文献と同時に Kaut をも視野に入れる必 要があるが, 注釈によって依拠する本文テキストが異なる場合がある ${ }^{10}$. 単独で出 版された注釈は Bhār, Medh, Kull のみであり,すべての注釈について調査するこ とは容易ではないが，いわゆる「流布本」 ${ }^{11)}$ の読みの困難が, 他の読みを採用する ことで解消される場合がある.ここではその一例として 7.114 を取り上げる. 


\section{7.114 の 2 種のテキスト}

Manu7.114 は村落や都市・国家の統治の仕組みを説く部分に含まれる.113で「rsaștra の samgraha のために以下の規定を実行せよ」と宣言され，以下 114 から 124 までが具体的な規定である。「流布本」のテキストは以下の通りである.

[1] dvayos trayānāạm pañcānām madhye gulmam adhișthitam /

tathā grāmaśatānām ca kuryāa rāștrasya samgraham //

Derrett の校訂した Bhār の本文テキストは若干異なる.

[2] dvayos trayāṇām pañcānām madhye gulmam adhiṣthitam /

tathā grāmaśatānāị ca kuryād rāstrasya guptaye //

問題は [1] の“samgraha”が難解なのではないかという点と, $\sqrt{\mathrm{kr}}$-の用法である.

\section{2. 注釈家の解釈と翻訳}

\section{2-1. [1] の解釈}

注釈の説明は以下の通りである.

rakșitrpurușasamūhas tenaivādhișțitam saṃrahạ̣ kuryāt / tadyuktam adhișthātāram puruṣam kuryāt / adhikārī samgraha ihocyate, evam trayānāạm pañcānām ca //Medh//

防衛を任務とする人の集まり，それによって統率された samgraha を設置せよ. それにふさ わしい統率者を任命せよ.ここでは指揮者のことを samgraha と言っているのである.この ように 3.5 カ村 [の中央に gulman を設置せよ].

àttapuruṣādhișthitam rāsțtrasya saṃgrahạ̣ rakșābhūtasthānakam kuryād, grāmadoṣādyavabodhanārtham karādigrahanārtham ca //Gov//

信頼できる人によって統率された rāstra の samgraha [即ち] 防衛施設としての sthānaka 設置せよ. 村落の問題点などを知らせることと, 税などの徵収を目的として.

gulmam rakșitrpurușasamūhasatyapradhānapuruṣādhișțhitāram rāṣtrasya saṃraham rakṣāsthānam kuryāt //Kull//

gulman [即ち] 防衛を任務とする人間の集まりで, 真実を第一とする人を指揮者とする rāșt$r a$ の samgraha を防衛施設として設置せよ.

rakșyasya sthānasya rakșakam gulumam stenādirakṣārthasthāpitam padātikādyadhișthitam iti tad api kenacid adhișthitam kāryam iti arthah / grāmaśatānām iti śatasya pañcaśatasya ceti bahuvacanārtham //Sarv//

守られるべき sthāna のための守備隊としての gulman は盗賊などから守ることを目的とし て設置され，歩兵などが統率されている．それはまた何者かによって統率されているとい 
う意味である. grāmaśatānāmm ${ }^{4)}$ とは 100 や 500 のように [100 が] 複数であることを意味する. gulmam rakșitṛurușasamūhamadhye pradhānapurușair adhișthitam ca rāṣ̦trasya samgraham rakșāsthānam kuryād iti anvayah //Rāgh//

gulman とは, 防衛を任務とする人間の集まりの中心にいる重要な人物によって統率され， rāstrtra の samgraha として, 防衛施設として設置せよ, と言うのが結論である.

dvayos trayānām pañ cānām madhye gulmam adhișthitam rakșakam svasthānam / evam rạș̣̦trasya samgraham kuryāt //Rām//

2,3,5 の村落の中央に, 統率された gulman を, 防衛 [施設] として, 物資の [集積] 場所を [設置せよ]. このように rāṣtraの samgraha を設置するべきである.

注釈家による samgraha の解釈は, < l > gulman の統率者, <2>王国防衛のための施 設，<3>貢物，税などの集積所，の 3 通りであり，近代以降の翻訳は，“王国を統治 する [ために]” (中野), “領国を守護すべし” (渡瀬), das in Ordnung Halten, Bewahren, Huten" $(P W)$, "a protection of the kingdom" (Bühler, Hopkins), "an adimistrator of state" (Jhā), "another (central post of guards) called samgraha" (Kane).

翻訳はいずれかの注釈に基づいているが，<3>の解釈はKaut に見られる samgrahana からの類推であろう ${ }^{5}$.

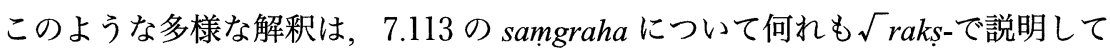
いるのと対照的である.

$2-2$. $\sqrt{k r}$-の用法

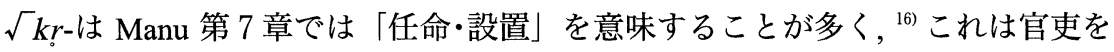
任命したり，諸施設を設置することが王の職務とされていることによる. samgraha を「統治」あるいは「守護」として, kuryāt の目的語と考える場合はこの用法では ない. しかし以下に述べる [2] の場合, kuryāt は「設置」の意味となり, 第 7 章の 他の用例との間に整合性が生じる.

$2-3$. [2] の立場

次に [2] の場合を検討してみよう. Bhār 自身の注釈は以下の通りである.

rājabhāryasamgrahārtham rakșārtham ca.

王のために集められたものを保管するため，また防衛のために．

他には Nandana が guptaye を採用している.

dvayor grāmayos trayānām pañ pāanām ca grāmānām grāmaśatāāām madhye rāstraguptaye kuryāt / vyüdham sainyam gulman //Nand//

2,3,5 の村落の, また 100 の村落の中央に rāștra の防衛のために. 兵士の陣営である gulman を [配置せよ]. 
この偈は Mitramiśra によって次のような形で引用される.

dvayos trayānām pañcānām madhye gulmam avasthitam /

tathā grāmaśatānām ca kuryād rāsstrasya guptaye //Vïramitrodaya, Rājanītiprakāśa, p. 248//

Mitramiśra は「rāṣtrasya samgraham と読むと, samgraha は防衛施設 (rakṣāsthāna) である」と説明し，[1] のテキストの存在をも知っている.

3. rāștra+gup-の例 : MBh $12.88^{7)}$

MBh12 の前半は rājadharmaparvan と呼ばれ, Manu 第 7 章と対応する偈が多い 12.88 は村落・国家の統治機構を扱う箇所で, Yudhișthiraは言う.

rāștraguptiṃ ca me rājan rāșțrasyaiva ca saṃgraham/

samyagjijñāsamānāya prabrūhi bharatarṣabha //MBh 12.88.1//

王よ私にとっての国家の防衛と, 国家の統治とを正しく知りたいのです. Bharata 族の最上 者よ, 語ってください

ここには「rāștraの samgraha」という表現があるが，この偈は章の冒頭の宣言で あり, 全体の構成から見ると以下に示す Manu7.113 と対応する.

rāṣṭasya saṃgrahe nityaṃ vidhānam idam ācaret/

susamgṛhìtarāșțre hi pārthivaḥ sukham edhate //Manu 7.113//

国家の統治 (samgraha) に際しては常に次の規定を実行せよ.

国家がよく治められるとき王は容易に繁栄するから．

したがってここでは「rāṣttraの samgraha」と同列に「rāșțra の gupti」が言及され ていることに注意しておきたい.

\section{4. まとめ}

以上の考察の結果をまとめると以下のようになるであろう.

(1)Manu. 7.114 のテキストには $2 つ の$ 伝承が現存している.

(2)流布している伝承 [1] では, “kuryāt … samgraham”の解釈に困難がある.

(3)文末を guptaye と読む伝承 [2] も複数の資料によって支持され，それは後代にま で及んでいる。

(4) [2] に従うと, 偈自体の解釈や前後の文脈とも整合性が高い.

(5)rāștra+gupti は他にも用例がある.

(6)従って, 7.114 のテキストとしては伝承 [2] が優越している可能性がある. 
Manu の注釈は以下の略号で示した.

略号：Bhār=Manuśāstravivaraṇa, Medh=Manubhāṣya, Gov=Manuṭikā,

Kull=Manvarthamuktāvalī, Sarv=Manvarthavivṛti, Rāgh=Manvarthacandrikā, Nand=Manuvyākhyāna.

1) M. Tokunaga : Structure of the Rājadharma Section in the Yãjñavalkyasmṛti (i. 309-368), (京都大学文学部紀要 32,1993 年 5 月, pp. 1-42) によって, Manu と Yājñavalkya との関係 が明らかになった.

2) SBE. vol. 25.

3) Manusmrti, Notes, pt. 3, Comparative, Calcutta, 1929.

4) The Laws of Manu, with the Bhāsya of Medhātithi, Calcutta, 1920-26 ; Manusmriti with the Manubhāsya of Medhātithi, Calucutta, 1932.

5) Bhāruci's Commentary on the Manusmṛti (The Manu-Śāstra-Vivaraṇa, Book6-12) Text, Translation and Notes, 2vols., Wiesbaden, 1975.

6) Newly-discovered Contact between Arthaśāstra and Dharmaśāstra : the Role of Bhāruci, ZDMG. CXV/1,1965,134-52.

7) Arthašāstra Studien, (I) Kauṭilya und Medhātithi, WZKSO. IX, 1965, pp. 1-38,

8) A jurist and his sources: Medhātithi's use of Bhāruci, $A L B$. XXX, 1967, pp. 1-22.

9) Derrett の指摘以外に，第 7 章に限ると 15,16,47,48,57,62-64,81,97,130,138,155-6,158,178, に Medh と Bhār に一致が見られる. また具体的な注釈を施さない箇所で Kaut に対応部 分がある場合, 両者とも「周知である (prasiddha, supratita)」とする場合もある.

10) 注 5. の vol. 1, APPENDIX III. に 300 以上の異読が指摘されている.

11) H. Brinkhaus : Bhāruci und Medhātithi zu Text und Inhalt von Manu X, 20, Studien zur Indologie und Iranistik, III, 1977, p. 71, n. 1. "Als Vulgata-Text bezeichnet man diejenige Version der Manusmriti, die zusammen mit dem Kommentar des Kullūka....$"$

12) [1] の立場で後代の綱要書 (14C.) に引用されている. Rājanītiratnākara (Kashi Samskrit Series 196, Varanasi, 1970) p. 117.

13) Bhār, Medh, Kull 以外は, V. N. Mandlik: Mānava-Dharma-Śāstra, New Delhi, 1992 (rep.) による.

14) “grāmaśatānām”は「数 100 の村」だが,「100の村」と解されることがある. Sarv は 「数 100」を意味することを注意している.

15) Kauț2.1.4;3.1.1 によると, samgrahana とは 10 村を統括する部署であり, 司法官 (dharmastha) が審理を行う場所でもある.

16) 114 以外に 54,60,61,63,78,81,115,121,123. 任命されるのは, 大臣, 使節, 祭官, 村長な

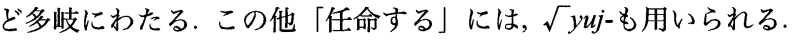

17）これ以外にも「rāsțra の防衛」の意味で $\sqrt{\text { gup }}$-と連合する例がある. MBh. 12.90.25; 12.120.29.

〈キーワード〉 Manusmṛti, Medhātithi, Bhāruch, saṃgrahaṇa, Arthašāstra 